\title{
Obituary
}

\section{MIKISO HANE}

(January 16, 1922-December 8, 2003)

The death of Mikiso Hane on December 8, 2003, following a relatively short illness, takes from the field of Japanese history of one of its most illustrious-and most humane-practitioners, a man who had taught thousands of students across four decades at Knox College in Galesburg, Illinois, and tutored even greater numbers of Americans in the intricacies of Japan's recent past. The author of fourteen books and many articles, Hane had pioneered in writing about those kinds of history that everyday Japanese of the modern era actually experienced.

Hane probably was best known through his four survey histories, including the widely used Modern Japan: A Historical Survey (Boulder, Colo.: Westview, 1986), which led the way for his American peers in making women, workers, and peasants a serious part of the narrative. He also provided scholars with a rich set of translations, including Maruyama Masao's Studies in the Intellectual History of Tokugawa Japan (Princeton, N.J.: Princeton University Press; Tokyo: University of Tokyo Press, 1974) and Honjō Shigeru's diary of the years preceding World War II (Emperor Hirobito and His Chief Aide-de-Camp [University of Tokyo Press, 1982]). Most influential, however, were his works on those people and groups who, until the last decade or two, have been ignored by most historians. Reflections on the Way to the Gallows: Rebel Women in Prewar Japan (Berkeley and Los Angeles: University of California Press, 1988) presents the writings of radical women of the late nineteenth and early twentieth century, women who fought for rights and agitated for revolutionary political change, often spending long periods in prison or even facing death for their activism. The most influential work of all was Peasants, Rebels, and Outcastes: The Underside of Modern Japan (New York: Pantheon, 1982), which told the stories of modernity's victims, opening the eyes of many undergraduates (as well as more than a few scholars) to the price that workers, women, miners, prostitutes, and commoners had to pay as Japan drove toward world prominence. "The peasants were seen primarily as resources to be exploited," wrote Hane. Japan's "leaders' aim was the same as that of the Tokugawa rulers: Squeeze sesame seeds and peasants as much as you can" (269). Although more recent works have examined this underside in increasingly nuanced ways, Hane's work broke open the path and set the early models for this kind of history.

The deep humanism that marked all of Hane's work was forged in a tumultuous upbringing that nurtured sensitivity and empathy rather than the bitterness that one might have expected. Born in Hollister, California, to immigrant parents on January 16, 1922, he was sent a decade later to live with an uncle in Hiroshima. He returned to California in 1940, when tensions between Japan and the United States began to mount, then was interned for eighteen months (1942-43) at an Arizona detention center for Japanese Americans. He ended the war as a Japanese-language teacher for the U.S. Army at Yale University, then stayed on to gain a BA, an MA, and in 1957 a $\mathrm{PhD}$. He taught at the University of Toledo prior to moving in 1961 to Knox College, where he became Szold Distinguished Professor of History. 
A peerless exemplar of the liberal arts, Hane taught courses in Western civilization - and in Japanese, Russian, Chinese, and Indian history, as well as in the Japanese language-even while producing scholarly works at a rate unequaled even by most contemporaries at major research universities. He also led numerous student programs to Japan and Hong Kong and served as informal advisor, consultant, and friend to scholars across the United States and Japan. He was unusually active in his profession, too, serving on the American Historical Association's Committee on Teaching, the board of directors of the Association for Asian Studies (AAS), and the AAS's Northeast Asia Council. In 1991 he was named by President George H. W. Bush to the National Council on the Humanities.

Hane continued to write and teach until last fall, when serious illness finally slowed him. In October 2003, the Midwest Conference on Asian Affairs, of which he had served as president in 1988, created the Mikiso Hane Undergraduate Research Prize in Asian Studies. He is survived by his wife, Rose Hane, of Galesburg, two daughters, and five brothers and sisters. Memorials may be given to the Mikiso Hane Fund for Asian Studies at Knox College.

JAMES L. HufFMAN

Wittenberg University 